\title{
Nutrient intake, digestibility and growth performance of Washera lambs fed natural pasture hay supplemented with graded levels of Ficus thonningii(Chibha) leaves as replacement for concentrate mixture
}

\author{
Yeshambel Mekuriaw and Bimrew Asmare*
}

\begin{abstract}
Background: The huge livestock resources of the country could not be used to its potential due to lack of goodquality feed throughout the year. Consequently, finding alternative feed supplements for livestock is an important step to sustain livestock production in the country. Ficus thonningii leaf is one of the potential feed resources for ruminants in the area. The experiment was conducted with the objective of evaluating the nutrient intake, digestibility and growth performance of local lambs fed natural pasture hay (NPH)-based diet supplemented with graded levels of Ficus thonningii dried leaves (FTL) and determining of the optimum level for replacing of concentrate mixture (CM). Twenty intact male yearling Washera lambs with initial body weight of $17.06+1.43$ (mean + SE) kg were used in experiment. The experiment was conducted using randomized complete block design having four replications with five dietary treatments. The treatments were $\mathrm{T} 1=\mathrm{NPH}+0 \mathrm{~g}$ FTL $+215 \mathrm{~g} \mathrm{CM} ; \mathrm{T} 2=\mathrm{NPH}+112.5 \mathrm{~g} \mathrm{FTL}+161.25 \mathrm{gCM}$; $\mathrm{T} 3=\mathrm{NPH}+225 \mathrm{~g} \mathrm{FTL}+107.5 \mathrm{~g} \mathrm{CM} ; \mathrm{T} 4=\mathrm{NPH}+337.5 \mathrm{~g} \mathrm{FTL}+53.75 \mathrm{~g} \mathrm{CM} ;$ and $\mathrm{T} 5=\mathrm{NPH}+450 \mathrm{~g} \mathrm{FTL}+0 \mathrm{~g}$ CM. Data were analyzed using the general linear model procedures of SAS (version 9.3; 2002).
\end{abstract}

Results: The results showed that FTL are a good source of crude protein (CP) (126.9 g/KgDM) and fibers (377-426 g/ $\mathrm{Kg} \mathrm{DM})$. Results also showed that supplementation of higher-level FTL significantly $(P<0.001)$ increased total DM, OM and fibers intake $(P<0.001)$, but no significant difference $(P>0.05)$ observed in $C P$ and $\mathrm{ME}$ intakes among treatments. Increasing level of FTL supplementation, however, reduced significantly $(P<0.001)$ the digestibility coefficient of all nutrients. In terms of ADG, nonsignificant $(P>0.05)$ differences were observed in lambs assigned up to $75 \%$ replacement of CM. The lowest performance was observed in sole FTL supplementation (T5), despite increased nutrients intake.

Conclusion: It was concluded that indigenous fodder tree Ficus thonningii leaves could serve as alternative CP supplement in NPH-based feeding of Washera sheep and can be used to replace CM up to 75\% to improve performance.

Keywords: Concentrate mixture, Ficus thonningii leaves, Grass hay, Washera lambs

\section{Background}

Ethiopia has huge and diversified livestock population than any African countries [1]. Among these livestock

*Correspondence: limasm2009@gmail.com Department of Animal Production and Technology, Bahir Dar University, P.O. Box 79, Bahir Dar, Ethiopia species existing in the country, sheep is the dominant one next to cattle [1].Recently, about 29 million sheep population has been estimated and reported in the country and the population is still increasing. Sheep are an important sub-sector of livestock farming, which is an integral part of the livelihood of the household level and contributes significantly to the national economy of Ethiopia [2]. 
Food, manure, skins, risk aversion are some of the important resources obtained from sheep for smallholder farmers. However, the contribution of the sub-sector both in smallholder farmer's and the country's economy remains below its potential due to low productivity of animals than the regional and continental average. The average reported carcass yield for Ethiopian sheep is $10 \mathrm{~kg}$ which is lower than the neighboring African countries sheep carcass weight such as Sudan (12 kg); Kenya (13 kg) and Djibouti $(14 \mathrm{~kg})$ [3]. This low productivity of animals could be reflected by many factors, but shortage of feed in terms of quality and quantity is the critical one in the country.

Nowadays, the most important livestock feed resources in Ethiopia are natural pasture, crop residues and grass hay $[1,3]$. The reliability of natural pasture as a source of feed is, however, restricted to the wet season [4] and most of it is degraded because of overgrazing [5]. Moreover, the resource is continuously converted to crop land to satisfy the food demand of an alarmingly increasing human population. Consequently, the natural pasture existing in the country has been characterized as poor in botanical composition, low nutritional quality and biomass yield. On the other hand, grass hay harvested from such areas could not satisfy the nitrogen requirements of sheep. Similarly, crop residues are inherently low in quality [6]. Hence, multipurpose fodder trees were introduced in the country just four decades ago aimed to supplement these major feed resources. However, these improved forage species production and utilization in the country is very minimal, with less than one percent [1]. Therefore, the basal diets like grass hay should be supplemented with commercial protein concentrates to satisfy maintenance and production requirements for critical nutrient like protein to enhance the rumen microbes which facilitate the degradation of fibrous feeds. In reality, protein concentrates are not easily available and affordable for the poor farmers in Ethiopia. Hence, looking other alternative protein sources from multipurpose fodder trees which are available especially during the dry season is vital and highly commendable.

The fodder value of Ficus thonningii tree leaves to different livestock species has been studied and reported [7-9]. Moreover, Balehegn et al. [10] reported that Ficus thonningii is a potential replacement for commercial concentrate for goat production. The proximate, in vitro and in sacco analysis studies made by scholars [11-13] indicated Ficus thonningii leaves to be a potential protein source $(11-14 \%)$ in ruminant nutrition. However, very limited information is available on the Ficus thonningii leaves for sheep production. Hence, the study was designed to evaluate the effect of graded level replacement of concentrate mixture with dried leaves of FT on nutrient intake, digestibility and performance of Washera lambs fed natural pasture hay basal feed.

\section{Methods \\ Study area}

The experiment was conducted at Zenzelima campus of Bahir Dar University, which is located between latitude and longitude of $11^{\circ} 37^{\prime} \mathrm{N}$ and $37^{\circ} 28^{\prime} \mathrm{E}$ coordinates and an elevation of $1912 \mathrm{~m}$ above sea level. The average daily minimum and maximum temperatures were 7 and $29{ }^{\circ} \mathrm{C}$, respectively. The average annual rainfall is $1445 \mathrm{~mm}$. The main rainy season is from June to September. The soils are dominantly nitosols (fertile agricultural soil).

\section{Experimental animals management and treatments}

Twenty intact male yearling Washera sheep with initial body weight of $17.06+1.43$ (mean $+\mathrm{SE}$ ) were purchased from Achefer and Dangila local markets. The age of the sheep was determined by dentition and information given from the owners. The animals were quarantined for 15 days at the experimental site in order to let the animals get accustomed to the specific environment and to observe their health situations. Meanwhile, the animals were vaccinated against common prevalent diseases of the area with the consultation of veterinarians from the college of agriculture and environmental sciences, Bahir Dar University. During the quarantine period, each animal was treated against internal parasites using albendazol and external parasite using ivermectin. Animals were continuously observed for incidence of any ill health and disorders during the experimental period.

The experimental animals were housed in individual pens in a ventilated shade that was built for this purpose. The pens were equipped with feeding trough for hay and plastic buckets for concentrates supplements and watering separately. The experimental sheep was identified with neck collars. Experimental animals were allowed to adapt the experimental diets for 15 days before the commencement of the actual data collection.

The design of the experiment was randomized complete block design (RCBD). Experimental animals were grouped into four blocks of five animals each based on their initial body weight, which was determined by the average of two consecutive weightings after overnight fasting. The experimental animals from each block were randomly assigned to each treatment feed. Natural pasture hay was provided as a basal diet and offered ad libitum with $20 \%$ refusal. The five experimental diets used both for feeding and digestibility trials are presented in Table 1. 
Table 1 Experimental treatment

\begin{tabular}{lllll}
\hline Treatments & Basal diet & \multicolumn{2}{l}{ Supplements } \\
\cline { 3 - 5 } & & CM (g/d) & FTL (g/d) & CP (g) \\
\hline T1 & NPH & $215(100 \%)$ & 0 & 57.62 \\
T2 & $\mathrm{NPH}$ & $161.25(75 \%)$ & $112.50(25 \%)$ & 57.49 \\
T3 & $\mathrm{NPH}$ & $107.50(50 \%)$ & $225.00(50 \%)$ & 57.36 \\
T4 & $\mathrm{NPH}$ & $53.75(25 \%)$ & $337.50(75 \%)$ & 57.23 \\
T5 & $\mathrm{NPH}$ & 0 & 450.00 & 57.11 \\
\hline
\end{tabular}

NPH natural pasture hay, FTL Ficus thonningii leaves, CM concentrate mixture; $\mathrm{T} 1=\mathrm{NPH}+0 \mathrm{~g} \mathrm{FTL}+215 \mathrm{~g} \mathrm{CM} ; \mathrm{T} 2=\mathrm{NPH}+112.5 \mathrm{~g} \mathrm{FTL}+161.25 \mathrm{~g} \mathrm{CM}$ $\mathrm{T} 3=\mathrm{NPH}+225 \mathrm{~g} \mathrm{FTL}+107.5 \mathrm{~g} \mathrm{CM} ; \mathrm{T} 4=\mathrm{NPH}+337.5 \mathrm{~g} \mathrm{FTL}+53.75 \mathrm{~g} \mathrm{CM}$; $\mathrm{T} 5=\mathrm{NPH}+450 \mathrm{~g} \mathrm{FTL}+0 \mathrm{~g} \mathrm{CM}$

\section{Feeds and feeding management}

The grass hay used in this study was natural pasture harvested in November 2014. Ficus thonningii leaves were collected in January 2015 (dry season) from farmers' arable land and backyard from different ages of the plant. Information was not obtained about the age of the trees. The leaves collected were transported to the experimental site and dried under shed. After drying, the leaves were thoroughly mixed to minimize variation. The natural pasture hay was chopped manually to the size of $3-10 \mathrm{~cm}$ so as to improve intake by experimental sheep. Noug seed cake and wheat bran were purchased from oil extraction and floor meal factories in Bahir Dar town. The grass hay was offered ad libitum along with free access of water and salt licks. The concentrate supplements, i.e., noug seed cake and wheat bran were mixed in 50:50 ratio, and the FTL was offered based on the proportions indicated in Table 1 .

\section{Chemical analysis}

The dried FTL and NPH samples were ground to pass through a 1-mm sieve (Willy mill) for chemical analysis. These ground samples were stored individually in an airtight plastic bag pending chemical analysis. Dry matter, $\mathrm{OM}$ and CP contents of FTL, NPH and CM were determined following the procedures described by AOAC [14]. The NDF, ADF and ADL contents were analyzed following the recommendations of VanSoest et al. [15].

\section{Feed intake}

Daily feed offered and refusals were collected from each treatment throughout the experimental period. The feeding or growth trial was lasted for 90 days. The daily feed intake of each experimental animal was calculated as the differences between feed offered and refused.

\section{Body weight change and feed efficiency}

Animals were weighted weekly in the morning after overnight fasting of the animal using Salter Scale with a sensitivity of $100 \mathrm{~g}$. The average daily weight gains (ADG) were calculated on a weekly basis. It was calculated as the difference between final BW and initial BW divided by a number of feeding days. The feed efficiency of experimental animals was determined by dividing the ADG into the amount of feed consumed.

\section{Digestibility}

The digestibility trial was conducted at the end of the feeding or growth trial. In the digestion trial, each sheep was fitted with fecal collection bags for 4 days of acclimatization period with fecal collection bags prior to the actual collection of feces for 7 consecutive days. Feces voided was thoroughly mixed, weighed and recorded every morning, and $20 \%$ of the representative samples was taken and frozen at $-10{ }^{\circ} \mathrm{C}$, and pooled over the collection period for each animal. At the end of the collection period, each sample was mixed and dried at $60{ }^{\circ} \mathrm{C}$ for $72 \mathrm{~h}$ at the college of Agriculture and environmental sciences laboratory. Then the samples of feces were taken to Debre birhan research center Animal Nutrition Laboratory for chemical analysis. The apparent digestibility of DM, OM, CP, NDF and ADF was determined using the following equations:

$$
\begin{aligned}
& \text { Apparent DM digestibility coefficient } \\
& \quad=\text { DMI - Faecal DM output } \\
& \text { DMIApparent nutrient digestibility coefficient } \\
& \quad=\text { Nutrient intake }- \text { Faecal nutrient output } \\
& \text { Nutrient intake } \\
& \text { where: DM = dry matter; DMI = dry matter intake }
\end{aligned}
$$

\section{Data analysis}

Feed intake, nutrients digestibility and performance of lambs' data were analyzed using the General Linear Model (GLM) procedures of SAS [16]. Means were separated using the least significant difference for variables when $F$ values declared a significant difference. Differences were considered statistically significant at $0.05 \%$ significance level.

The analysis model was:

$$
Y_{i j}=\mu+t_{i}+b_{j}+e_{i j}
$$

where $Y_{i j}=$ dependent variables, $\mu=$ overall mean, $t_{i}=$ the effect of the $i$ th treatments, $b_{j}=$ effect of the $j$ th block and $e_{\mathrm{ij}}=$ random error of $i$ th treatment in the $j$ th block. 


\section{Results}

Chemical composition of the treatment feeds

The chemical composition of feed components consisting treatment diets is presented in Table 2. Almost similar amount of dry matter (DM) is obtained in the feed components of the treatment diet. Higher crude protein (CP) content was recorded in FTL than natural pasture hay (NPH). Similarly, FTL showed lower fiber (NDF, ADF and ADL) contents than NPH. The concentrate mixture of wheat bran and noug seed cake (50:50) proportion had better nutritive value when evaluated in terms of CP and fiber contents as compared to FTL.

\section{Feed and nutrient intake}

The daily DM and nutrient intake of Washera lambs fed natural pasture hay and supplemented with different levels of ficus leaves and concentrate mixture is presented in Table 3. There was a significant difference $(P<0.001)$ between $\mathrm{T} 1$ and $\mathrm{T} 5$ in terms of total DM (TDM), DM (\% BW) and OM intake. In general, intake parameters increased as the level of FTL increased. On the other hand, lowest TDM, (\% BW) and OM intake were observed in sole CM-supplemented group (T1) while the highest for sole FTL-supplemented group (T5). Similarly, fibers (NDF, ADF, ADL) intake also significantly $(P<0.001)$ varied among treatments and their intake increased as the FTL inclusion increased. However, a nonsignificant difference $(P>0.05)$ was observed in $\mathrm{CP}$ and $\mathrm{ME}$ intake among treatments.

\section{Dry matter and nutrient digestibility coefficient}

Apparent digestibility coefficients of DM and nutrients in Washera lambs fed NPH and supplemented with noug seed cake and wheat bran mixture and dried FTL is presented in Table 4. A significant difference $(P<0.001)$ was observed between sole CM supplement (T1) and sole.

FTL supplement (T5) in terms of DM, OM and fibers digestibility coefficient. However, significant difference $(P>0.05)$ was not observed among treatments $(\mathrm{T} 1$, $\mathrm{T} 2, \mathrm{~T} 3$ and $\mathrm{T} 4$ ) in terms of digestibility coefficients.

Table 2 Chemical composition of feed used in the experiments

\begin{tabular}{|c|c|c|c|c|c|c|}
\hline \multirow[t]{2}{*}{ Feeds } & \multicolumn{6}{|c|}{ Chemical composition (g/Kg for DM and $\mathrm{g} / \mathrm{Kg} \mathrm{DM}$ for others) } \\
\hline & DM & OM & $\mathrm{CP}$ & NDF & ADF & $A D L$ \\
\hline $\mathrm{NPH}$ & 890.0 & 830.0 & 38.8 & 768.6 & 448.6 & 150.0 \\
\hline FT L & 900.0 & 789.0 & 126.9 & 426.5 & 377.8 & 126.8 \\
\hline NSC & 900.0 & 922.0 & 356.4 & 406.5 & 282.6 & 108.8 \\
\hline WB & 910.0 & 952.5 & 194.4 & 286.9 & 173.9 & 90.6 \\
\hline CM & 910.0 & 913.0 & 226.8 & 366.8 & 260.8 & 106.8 \\
\hline
\end{tabular}

NPH natural pasture hay, FTL Ficus thonningii leaves, CM noug seed cake: Wheat bran (50:50)

Table 3 Feed intake of Washera lambs fed natural pasture hay supplemented with different levels of Ficus leaves and concentrate mixture

\begin{tabular}{|c|c|c|c|c|c|c|c|}
\hline \multirow[t]{2}{*}{ Parameters } & \multicolumn{5}{|c|}{ Treatments } & \multirow[t]{2}{*}{ SEM } & \multirow[t]{2}{*}{ SL } \\
\hline & $\mathrm{T} 1$ & $\mathrm{~T} 2$ & T3 & $\mathrm{T4}$ & T5 & & \\
\hline Basal DMI (g/d) & $472.62^{a}$ & $452.79^{\mathrm{ab}}$ & $445.93^{\mathrm{ab}}$ & $421.61^{b}$ & $424.82^{\mathrm{ab}}$ & 11.073 & $* * *$ \\
\hline Supplement DM intake (g/d) & $195.7^{e}$ & $248.0^{d}$ & $300.3^{c}$ & $352.7^{b}$ & $405.0^{\mathrm{a}}$ & 0.000 & *** \\
\hline Total DMI (g/d) & $668.27^{d}$ & $700.48^{c d}$ & $746.78^{\mathrm{bc}}$ & $774.27^{b}$ & $829.82^{\mathrm{a}}$ & 11.073 & $* * *$ \\
\hline TDMI (\%BW) & $2.72^{c}$ & $2.99^{\mathrm{bc}}$ & $3.27^{b}$ & $3.44^{\mathrm{ab}}$ & $3.90^{\mathrm{a}}$ & 0.114 & $* * *$ \\
\hline OMI (g/d) & $570.90^{d}$ & $589.68^{c d}$ & $619.21^{b c}$ & $634.25^{\mathrm{ab}}$ & $672.15^{\mathrm{a}}$ & 9.190 & $* * *$ \\
\hline CPI (g/d) & $55.59^{\mathrm{a}}$ & $54.99^{\mathrm{a}}$ & $54.82^{\mathrm{a}}$ & $54.23^{\mathrm{a}}$ & $54.09^{a}$ & 0.357 & ns \\
\hline $\operatorname{NDFI}(g / d)$ & $367.02^{b}$ & $372.09^{b}$ & $385.38^{\mathrm{ab}}$ & $387.56^{\mathrm{a}}$ & $407.30^{\mathrm{a}}$ & 7.063 & $* * *$ \\
\hline $\operatorname{ADFI}(g / d)$ & $222.56^{\mathrm{d}}$ & $233.72^{\mathrm{cd}}$ & $249.70^{b c}$ & $259.18^{b}$ & $278.89^{\mathrm{a}}$ & 4.123 & $* * *$ \\
\hline ADLI (g/d) & $77.918^{d}$ & $80.81^{c d}$ & $85.32^{\mathrm{bc}}$ & $87.650^{\mathrm{ab}}$ & $93.41^{\mathrm{a}}$ & 1.378 & $* * *$ \\
\hline${ }^{1} \mathrm{MEI}(\mathrm{MJ} / \mathrm{Kg} \mathrm{DM})$ & $7.12^{\mathrm{a}}$ & $7.16^{\mathrm{a}}$ & $7.29^{\mathrm{a}}$ & $7.31^{\mathrm{a}}$ & $7.48^{\mathrm{a}}$ & 0.174 & ns \\
\hline
\end{tabular}

$\mathrm{a}, \mathrm{b}, \mathrm{c}, \mathrm{d}, \mathrm{e}=$ means within rows having different superscript are significantly different at ${ }^{* * *}=(p<0.001)$; ADF acid detergent fiber, $B W$ body weight, $C M$ concentrate mixture, CP crude protein, DMI dry matter intake, NDF neutral detergent fiber, OM organic matter, SL significant level, NPH natural pasture hay, FTL Ficus thonningii leaves, $C M$ concentrate mixture; $\mathrm{T} 1=\mathrm{NPH}+0 \mathrm{~g} \mathrm{FTL}+215 \mathrm{~g} \mathrm{CM} ; \mathrm{T} 2=\mathrm{NPH}+112.5 \mathrm{~g} \mathrm{FTL}+161.25 \mathrm{~g} \mathrm{CM} ; \mathrm{T} 3=\mathrm{NPH}+225 \mathrm{~g} \mathrm{FTL}+107.5 \mathrm{~g} C M ; \mathrm{T} 4=\mathrm{NPH}+337.5 \mathrm{~g}$ FTL $+53.75 \mathrm{~g} \mathrm{CM} ; \mathrm{T} 5=\mathrm{NPH}+450 \mathrm{~g} \mathrm{FTL}+0 \mathrm{~g} \mathrm{CM}$

${ }^{1}$ Estimated Metabolizable Energy $(\mathrm{ME})=0.0157 \times$ Digestible Organic Matter Intake (DOMI) [46] 
Table 4 Apparent digestibility coefficients of nutrients in sheep fed natural pasture hay mixture as a basal diet and supplemented with noug seed cake and wheat bran mixture and ficus leaves

\begin{tabular}{|c|c|c|c|c|c|c|c|}
\hline \multirow[t]{2}{*}{ Parameters } & \multicolumn{7}{|c|}{ Treatments (\%) } \\
\hline & T1 & $\mathrm{T} 2$ & T3 & T4 & T5 & SEM & SL \\
\hline DMDC & $0.77^{a}$ & $0.75^{\mathrm{a}}$ & $0.73^{a b}$ & $0.71^{a b}$ & $0.69^{b}$ & 0.012 & $* * *$ \\
\hline OMDC & $0.79^{a}$ & $0.78^{a b}$ & $0.75^{a b c}$ & $0.74^{b c}$ & $0.71^{c}$ & 0.011 & $* * *$ \\
\hline CPDC & $0.79^{a}$ & $0.77^{\mathrm{a}}$ & $0.69^{b}$ & $0.62^{c}$ & $0.60^{c}$ & 0.013 & $* * *$ \\
\hline NDFDC & $0.66^{\mathrm{a}}$ & $0.58^{a b}$ & $0.54^{a b}$ & $0.51^{a b}$ & $0.44^{b}$ & 0.040 & $* * *$ \\
\hline ADFDC & $0.63^{a}$ & $0.56^{a b}$ & $0.53^{a b c}$ & $0.49^{b c}$ & $0.42^{c}$ & 0.042 & $* * *$ \\
\hline
\end{tabular}

Significant difference $(P<0.001)$ was observed in $\mathrm{CP}$ digestibility coefficient among treatments in the following ranking $(\mathrm{T} 1=\mathrm{T} 2>\mathrm{T} 3>\mathrm{T} 4=\mathrm{T} 5)$.

\section{Body weight gains and feed efficiency}

The average daily gain and feed efficiency of Washera lamb are presented in Table 5. A significant difference $(P<0.001)$ was observed between sole $C M$-supplemented (T1) and sole FTL-supplemented (T5) groups in terms of ADG and FE. However, significant difference $(P>0.05)$ was not observed among treatments (T1, T2, T3 and T4) and in FTL-supplemented groups (T2-T5) in terms of ADG. Among the FTL-supplemented groups, T5 had the lowest FE value.

\section{Discussion}

\section{Chemical composition of treatment feeds}

The natural pasture hay $(\mathrm{NPH})$ used in the current study had very low CP content (38.8 g/ kg DM) which is below the $\mathrm{CP}$ requirement for ruminant animals for proper rumen function $[17,18]$. CP content $(38.8 \mathrm{~g} / \mathrm{kg}$ $\mathrm{DM}$ ) of NPH obtained in current study is similar with the value reported by [19-21] and lower than the values
(70.2-92 g/kg DM) reported by [21-24].The obtained fiber content of NPH in this study is within the expected ranges of most tropical roughage feedstuffs, but the NDF values are comparable with the values reported by [19, $23]$ but lower than the values reported by [20, 22] and higher than the value reported by Asmare et al. [21].

Similar values were obtained with regard to ADF, by many authors [20, 23, 24] and lower than the values reported by Mekuriaw et al. [22] Ephrem et al. [19] and higher than the value reported by Asmare et al. [23]. Higher level of ADL recorded in this study was comparable with the values reported by [20-22, 24] and Asmare et al. [23], but lower than the values reported by Ephrem et al. [19],but similar with value reported by Asmare et al. [23]. This fiber contents difference among studies could be explained by altitude, rainfall, harvesting stage, fertility, soil and cropping intensity variation $[25,26]$. The fiber fraction of hay in the current study is within the range of most tropical forages $(<45 \%$ for high quality, $45-65 \%$ for medium quality and $>65 \%$ for poor quality roughages) [27] indicating that the hay is poor in quality for optimum rumen condition and supplementation of this natural pasture hay with alternative protein source was commendable.

Table 5 Body weight measurements and feed efficiency of sheep fed on natural pasture hay and supplemented with noug seed cake and wheat bran in 50:50 ratio and ficus leaves

\begin{tabular}{|c|c|c|c|c|c|c|c|}
\hline \multirow[t]{2}{*}{ Parameters } & \multicolumn{7}{|c|}{ Treatments } \\
\hline & $\mathrm{T} 1$ & $\mathrm{~T} 2$ & T3 & $\mathrm{T4}$ & T5 & SEM & SL \\
\hline IBW & $16.28^{a}$ & $17.53^{\mathrm{a}}$ & $17.53^{a}$ & $17.95^{\mathrm{a}}$ & $17.33^{a}$ & 1.331 & ns \\
\hline FBW & $22.80^{a}$ & $22.30^{a}$ & $21.98^{a}$ & $21.55^{\mathrm{a}}$ & $21.13^{a}$ & 1.175 & ns \\
\hline ADG & $67.50^{\mathrm{a}}$ & $63.89^{a b}$ & $56.39^{a b}$ & $55.28^{\mathrm{ab}}$ & $53.62^{b}$ & 4.212 & $* * *$ \\
\hline $\mathrm{FE}$ & $0.10^{a}$ & $0.083^{a b}$ & $0.073^{b c}$ & $0.060^{c d}$ & $0.050^{d}$ & 0.014 & $* * *$ \\
\hline
\end{tabular}

$\mathrm{a}, \mathrm{b}, \mathrm{c}=$ means within rows having different superscript are significantly different at $P<0.001 ; A D G$ average daily gain, $B W C$ body weight change, $F B W$ final body weight, IBW initial body weight, FCE feed conversion efficiency, NPH natural pasture hay, FTL Ficus thonningii leaves; $C M$ concentrate mixture; **** $(P<0.001)$; $\mathrm{T} 1=\mathrm{NPH}+0 \mathrm{~g} \mathrm{FTL}+215 \mathrm{~g} \mathrm{CM} ; \mathrm{T} 2=\mathrm{NPH}+112.5 \mathrm{~g} \mathrm{FTL}+161.25 \mathrm{~g} \mathrm{CM} ; \mathrm{T} 3=\mathrm{NPH}+225 \mathrm{~g} \mathrm{FTL}+107.5 \mathrm{~g} \mathrm{CM} ; \mathrm{T} 4=\mathrm{NPH}+337.5 \mathrm{~g} \mathrm{FTL}+53.75 \mathrm{~g}$ CM;

$\mathrm{T} 5=\mathrm{NPH}+450 \mathrm{~g} \mathrm{FTL}+0 \mathrm{~g} \mathrm{CM}$ 
The CP content of $126.9 \mathrm{~g} / \mathrm{kgDM}$ noted in the current study for Ficus thonningii was quite similar with data ranging from 102.4 to $154.1 \mathrm{~g} / \mathrm{kg}$ DM [12, 13, 28-31], but lower than the values 164.7 to $248.8 \mathrm{~g} / \mathrm{kgDM}$ as reported by $[7,10,32-35]$. This difference could be explained by the season and age of the plants where samples were collected. The same author Funmilayo et al. [28] reported the effect of season on the nutritional value of FTL. Balehegn et al. [10] also reported the nutritional value of leaf of Ficus plant could be affected by the age at which the sample is collected. In general, FTL had better CP content being beyond the maintenance requirement of ruminant animals. The CP content $8 \%(80 \mathrm{~g} / \mathrm{kg} \mathrm{DM})$ obtained in FTL can provide the minimum ammonia levels required for microbial activity in ruminants [36].

Fiber contents of FTL (426.5, 377.8 and $126.8 \mathrm{~g} / \mathrm{Kg} \mathrm{DM})$ for NDF, ADF and ADL, respectively, obtained in the current study were lower than the ficus leaves used by Kassahun et al. [12]. (NDF, ADF, ADL=47.61, 39.49, $20.28 \mathrm{~g}$ / kg DM), Dupe and Olaniyi [29] (NDF, ADF, ADL =640, 480, $120 \mathrm{~g} / \mathrm{kg} \mathrm{DM}$ ), Njidda and Ikhimioya [32] (NDF, $\mathrm{ADF}, \mathrm{ADL}=512 ; 412 ; 100 \mathrm{~g} / \mathrm{kg} \mathrm{DM})$, Bruh and Destalem [13] (NDF, ADF, ADL=640, 392, 74.4 g/kgDM), Yousuf and Ogundun [30] (NDF and $\mathrm{ADL}=419.7 ; 291.1 \mathrm{~g} / \mathrm{kg}$ $\mathrm{DM}$ ) in shed ficus leaf, Balehegn et al. [13] (NDF, ADF, $\mathrm{ADL}=427,365,162.3 \mathrm{~g} / \mathrm{kg} \mathrm{DM}$ ) and $\mathrm{NDF}=557.9$ [34]. The possible explanation for these differences could be the environment where plants are grown, the season or age of the plant [28]. Higher CP (226.6 g/kg DM) and lower fiber contents (260-366 g/Kg DM) were observed in $\mathrm{CM}$ as compared to the FTL in terms of these nutrients. The overall variability in fiber nutrient composition could be attributed to various factors such as plant age, harvesting regime, season and location. These factors should be considered when carrying out the chemical evaluation of fodder trees.

\section{Dry matter and nutrient intake}

Natural pasture grass hay intake by all treatment groups obtained in the current study (424-472 g/day) was higher than the value (415 g/day) reported by Ephrem et al. [19] for natural pasture hay and by Tefera et al. [37] for Rhodes grass consumed by the same sheep breed. The total DM intake was more than sufficient to meet maintenance requirement for DM $(2-2.5 \% \mathrm{BW})$. In line with the current study (put the value of the fiber content of CM here), Balehegn et al. [10] also observed improved DM and nutrient intake when FTL was replaced by concentrate supplement in the highland goats. The total DM intake of sheep in the current study was similar with the results obtained by Kassa et al. [38] for the same breed of sheep fed hay as a basal diet and supplemented with F. sycomorous leaf, fruit and their mixtures. However, the total DM intake was lower than the reports of Tadelle et al. [39] for the same breed of sheep fed natural pasture hay supplemented with processed lupin grain (Lupinus albus).

Total DM intake of the current study is lower than the values reported (666-788 g/day) for Farta sheep supplemented with wheat bran, noug seed cake and their mixtures [20]. The mean total DM intake of sheep in the current study was 58.08 g DM kg-1 W0.75 which was similar with the results of other works $[40,41]$ who reported total DM intake of sheep being within the range of 58.6-82.2 $\mathrm{g} \mathrm{DM} \mathrm{kg}^{-1} \mathrm{~W} 0.75$. The total DM intake expressed as percent of body weight obtained from the current study is in agreement with that of Kitaw et al. [42] with the value being in the range of the recommended dry matter intake of ruminants $(2-6 \%)$ by ARC [43].

\section{Apparent nutrient digestibility}

The lower apparent DM and nutrient digestibility in the sole FTL indicated that sole FTL might not be used solely as a supplement of sheep in such type of basal diet (Table 4). However, FTL can be used as supplement up to $75 \%$ in total supplements as there were relatively better digestibility coefficients in such treatment diets except for $100 \%$ FTL supplement group.

The better digestibility coefficient up to 75\% FTL supplement might be due to the fact that the higher protein content might have increased the digestibility of the crude fiber of the feeds. If the protein-rich feeds are added to balance low protein roughages, there will be an increased population of the microorganism which increased the rate of fermentation of the crude fiber component [44]. The lower digestibility of nutrients observed as FTL supplementation increased from 0 to $100 \%$ might be associated with the higher fiber fraction both in the basal diet and FTL supplement. This observed lower digestibility of nutrients among sheep assigned under higher FTL might be due to the higher fiber intake. This idea was supported by Gemeda and Hassen [45] who reported negative effects on voluntary feed intake and nutrient digestibility.

\section{Body weight change}

The positive weight gain observed in the control group in the current study was due to the inclusion of $\mathrm{CM}$ (Table 2) beyond their microbial nutrient requirement (VanSoest, 1994). ADG of Washera lambs assigned in FTL of the current study showed similar gains by Ephrem et al. [19] using similar sheep breed feeding sweet lupin as a protein supplement. Similarly, increasing the level of FTL supplementation improved ADG $(P<0.001)$ of Washera lambs (47.8-74.7 g/day). Balehegn et al. [10] also reported similar results on goats fed ficus leaf in 
Tigray, Ethiopia. The same authors reported that in goat up to the level of $50 \%$ concentrate replacement with FTL improved intake and performance of goat. In the current study even though the level of FTL inclusion increased the values are almost the same with sole CM but the lowest level of digestibility and growth performance observed in the sole FTL. Contrary to the current study, Yousuf and Ogundun [30] reported fallen FTL fed goat showed negative weight gain. However, practical limitation was not observed due to utilization of FTL solely in ruminant feeding [34].

\section{Conclusion}

From the current study, it is possible to conclude that supplementation of Washera lambs with Ficus thonningii leaves by replacing concentrate mix up to the $75 \%$ inclusion for optimum performance of improved nutrient intake, digestibility and growth of sheep and this multipurpose indigenous fodder tree (Ficus thonningii) leaves could serve as an alternative CP supplement in the natural pasture hay-based feeding system of Washera sheep in the dry season when most forages could not supply enough nitrogen for the function of rumen in ruminant animals.

\begin{abstract}
Abbreviation
ADF: acid detergent fiber; ADG: average daily gain; ADL: acid detergent lignin; AOAC: association of official analytical chemists; BW: body weight; CP: crude protein; CSA: central statistical agency; DM: dry matter; DMl: dry matter intake; DMD: dry matter digestibility; DOM: digestible organic matter; DOMl: digestible organic matter intake; FT: Ficus thonningii; FTL: Ficus thonningii leaves; FCE: feed conversion efficiency; GLM: general linear model; ME: metabolizable energy; MJ: mega joule; NDF: neutral detergent fiber; NPH: natural pasture hay; NSC: noug seed cake; OM: organic matter; OMDC: organic matter digestibility coefficient; OMl: organic matter intake; RCBD: randomized complete block design; SAS: statistical analysis system.
\end{abstract}

\section{Authors' contributions}

BA contributed in research proposal writing, data collection, data analysis, data interpretation and article writing. YM contributed in research data collection, data analysis, data interpretation and article writing. Both authors read and approved the final manuscript.

\section{Authors' information}

Asmare is an Assistant Professor of Animal Feeds and Nutrition, currently teaching and conducting research in the area of animal feeds and feeding, animal production and productivity improvement in Ethiopia. Mekuriaw is an Associate Professor of Animal Feeds and Nutrition, currently teaching and conducting research in the area of animal feeds and feeding, animal production and productivity improvement in Ethiopia.

\section{Acknowledgements}

The authors acknowledge Bahir Dar University, College of Agriculture and Environmental Sciences for the financial support to do the feeding and digestibility trials and Debre Berhan Agricultural Research Center Animal Nutrition Laboratory for assisting in laboratory chemical analysis of feeds and feces. The authors also would like to extend our thanks to reviewers who gave very crucial points to improve the paper.
Competing interests

Both authors declare that they have no competing interests.

\section{Availability of supporting data}

The datasets used and/or analyzed during the current study available from the corresponding author on reasonable request.

\section{Consent for publication}

Not applicable.

Ethical approval and consent to participate

Not applicable.

Funding

Bahir Dar University, College of Agriculture and Environmental Sciences.

\section{Publisher's Note}

Springer Nature remains neutral with regard to jurisdictional claims in published maps and institutional affiliations.

Received: 16 January 2017 Accepted: 28 March 2018

Published online: 16 April 2018

\section{References}

1. CSA. Agricultural sample survey, vol. II report on livestock and livestock characteristics. CSA (Central Statistical Agency), 2013, Addis Ababa, Ethiopia.

2. Gizaw S, van Arendonk JAM, Komen H, Windig JJ, Hanotte O. Population structure, genetic variation and morphological diversity in indigenous sheep of Ethiopia. AnimalGenetics. 2007;38:621-8.

3. Tegegne F, Assefa G. Feed resources assessment in Amhara National Regional State.Ethiopia Sanitary and Phytosanitary Standards and Livestock and Meat Marketing Program(SPS-LMM, Texas Agricultural Experiment Station (TAES). Final Report, Bahir Dar, Ethiopia. 2010: 81-94.

4. Zinash S, Seyoum B, Lulseged G, Tadesse T. Effect of harvesting stage on yield and quality of natural pasture in the central highlands of Ethiopia. In: Proceedings of third National Conference of the Ethiopian Society of Animal Production (ESAP), pp. 316-322,1995, Addis Ababa, Ethiopia.

5. Alemayehu M. Country Pasture/Forage Resource Profiles: Ethiopia. 2006 Available at http://www.fao.org/AGp/agpc/doc/counprof Ethiopia.htm. Accessed on 10 Aug 2016.

6. Wondatir Z, Mekasha Y. Feed resources availability and livestock production in the central rift valley of Ethiopia. Int J Livest Prod. 2014;5:30-5.

7. Jokthan GE, Afikwu EV, Olugbemi TS. The utilization of fig (Ficus thonningii) and mango (Mangifera indica) leaves by rabbits. Pak J Nutr. 2003:2:264-6.

8. Tegbe TSB, Adeyinka IA, Baye KD, Alawa JP. Evaluation of feeding graded levels of dried and milled Ficus thonningii leaves on growth performance, carcass characteristics and organs of Weaner Rabbits. Pak J Nutr. 2006;5:548-50

9. Bamikole MA, Ikhatua UJ, Arigbede OM, Babayemi OJ, Etela I. An evaluation of acceptability as forage of some nutritive and antinutritive components and of the dry matter degradation profiles of five species of ficus. Trop Anim Health Prod. 2004;36:157-67.

10. Balehegn M, Eik LO, Tesfay Y. Replacing commercial concentrate by Ficus thonningii improved productivity of goats in Ethiopia. Trop Anim Health Prod. 2014;46:889-94.

11. Berhe DH, Tanga AA. A. nutritional evaluation of Ficus thonningii Blume leaves as ruminant livestock feed in the Ahferom district of Tigray, Ethiopia. Afr J Range Forage Sci. 2013;30:149-54.

12. Desalegn $K$, Meksasha $Y$, Assefa G. Identification and nutritional value assessment of the major browse species in Chilega District, North Gondar. Glob Vet. 2016;16:06-17.

13. Bruh W, Destalem G. Identification and determination of chemical composition of some potential browses as livestock fodder in the Central and North Western Zones of Tigray, Ethiopia. Livest Res Rural Dev. 2015: 27. 
14. AOAC 1990 Official method of analysis. AOAC (Association of Official Analytical Chemists) 15th ed. AOAC Inc., Arlington, Virginia, USA. 1990:12-98.

15. Van Soest PJ, Robertson JB, Lewis BA. Methods for dietary fiber, neutral detergent fiber and non-starch polysaccharides in relation to animal nutrition. J Dairy Sci. 1991;74:3583-97.

16. SAS. Statistical Analysis System, Version 9.3. SAS (Statistical Analysis System), Institute Inc., 2002. Cary, NC, USA.

17. Van Soest PJ. Nutritional ecology of the ruminant. 2 nd ed. London: Cornell University; 1994. p. 244-52.

18. McDonald AA, Edwards R A, Greenhalgh JFD, Morgan CA. Animal nutrition, 6th ed. pp. 2002:187-198, 544-549.

19. Ephrem N, Tegegne F, Mekuriaw Y, Yiheyis L. Nutrient intake, digestibility and growth performance of Washera lambs supplemented with graded levels of sweet blue lupin (Lupinus angustifolius L.) seed. Small Rumin Res. 2015;130:101-7.

20. Bishaw F, Melaku S. Feed utilization and live weight change of Farta sheep supplemented with noug seed meal and wheat bran on feed intake, digestibility and body weight change. Trop Anim Health Prod. 2008;40:597-606

21. Asmare A, Solomon D, Taye T, Firew T, Jane W, Barbara R. Determinants of the utilization of desho grass (Pennisetum pedicellatum) by farmers in Ethiopia. Trop Grassl.-Forrajes Trop. 2016:4:112-21.

22. Mekuriaw Y, Urge M, Animut G. Intake, digestibility, live weight changes and rumen parameters of Washera sheep fed mixtures of lowland bamboo (Oxytenanthera abyssinica) leaves and natural pasture grass hay at different ratios. Pak J Nutr. 2012;11:322-31.

23. Asmare B, Melaku S, Peters Kurt J. Supplementation of Farta sheep fed hay with graded levels of concentrate mix consisting of noug seed meal and rice bran. Trop Anim Health Prod. 2010:42:1345-52.

24. Nega A, Melaku S. Feed intake, digestibility and body weight change in Farta sheep fed hay supplemented with rice bran and/or noug seed (Guizotia abyssinica) meal. Trop Anim Health Prod. 2008;41:507-15.

25. Denekew Y, Tamir B, Melaku S. Effect of harvesting date on composition and yield of natural pasture in north western Ethiopia. Trop Sci. 2005:45:19-22.

26. Kitaba A, Tamir B. Effect of harvesting stage and nutrient levels on nutritive values of natural pasture in central highlands of Ethiopia. Agric Tropica et Subtrop. 2007:40:1-10.

27. Lemus R Hay storage: Dry matter losses and quality changes. Mississippi State University Extension Service, USA. 2009. Accessed 25 Sept 2016.

28. Funmilayo B, Olaniyi B and Adegboyega A. Feed resources and seasonal nutrient composition of predominant forages for small ruminant production in iwo local Government Area of Osun state, Nigeria. J Biol Agric Healthc. 2013:17.

29. Dupe OO, Olaniyi JB. The effect of forage based diets on milk composition, lactation stages and growth rate kids from West African dwarf (WAD) goat in South West Nigeria.

30. Conference on International Research on Food Security, Natural Resource Management and Rural Development. ETH Zurich, Sept 14-16, 2010.

31. Yousuf MB, Ogundun NJ. Feeding value of shed or fresh Ficus (Ficus thonningii) leaves for the West African dwarf. J Centrepoint. 2005;13:51-9.

32. Yusuf AO, Muritala RO. Nutritional evaluation and phytochemical screening of common plants used in smallholder farming system. Pac J Sci Technol. 2013;14:12-8.
33. Njidda AA, Ikhimioya I. In vitro gas production and dry matter digestibility of semi-arid browses of North Eastern Nigeria. Slovak J Anim Sci. 2010;43:154-9.

34. Otitoju GTO, Nwamarah JU, Otitoju O, lyeghe LU. Nutrient composition of some lesser known green leafy vegetables in Nsukka Lga of Enugu State. J Biodivers Environ Sci. 2014;4:233-9.

35. Gemeda BS, Hassen A. Effect of Tannin and species variation on In vitro digestibility, gas, and methane production of tropical browse plants. Asian Australas J Anim Sci. 2015;28(2):188-99.

36. Musibau A, Bamikole U, Julius I. Nutritional evaluation of Ficus thonningiiPanicum maximum mixtures in West African dwarf goats. Nutr Food Sci. 2010:40:280-8

37. Norton BW. Anti-nutritive and toxic factors in forage tree legumes. In Forage Tree Legumes in Tropical Agriculture. Edited by: Gutteridge RC, Shelton HM. CAB International, Wallingford, Oxford; 1994: 202-215.

38. Tefera G, Tegegne F, Mekuriaw Y, Melaku S and Tsunekawa A. Effects of different forms of white lupin (Lupinus albus) grain supplementation on feed intake, digestibility, growth performance and carcass characteristics of Washera sheep fed Rhodes grass (Chloris gayana) hay-based diets. Trop Anim. Health Prod. 2015:47.

39. Kassa A, Tadele Y, Mekasha Y. Ficus sycomorus (Sycamore Fig or Shola) leaf, a potential source of protein for ruminants: a review. J Fisheries Livest Prod. 2015:3:4-11.

40. Tadele Y, Mekasha Y, Tegegne F. Supplementation with different forms of processed Lupin (Lupinus albus) grain in hay based feeding of Washera sheep: effect on feed intake, digestibility body weight and carcass parameters. J Biol Agric Healthc. 2014;4:27-35.

41. FAO. Successes and failures with animal nutrition practices and technologies in developing countries. Proceedings of the FAO (Food and Agricultural Organization of the United Nations) Electronic Conference, 1-30 September 2010. Editor H P S Makkar. FAO Animal Production and Health Proceedings. No. 11. Rome, Italy.

42. Alem M, Tamir B, Kurtu MY. Feed utilization of Ethiopian highland lambs on a basal diet of eleucine coracana straw and supplemented with variously sourced protein mixed with wheat bran. Trop Anim Health Prod. 2011:43:115-20.

43. Kitaw G, Dejene M, Kahilew A, Assefa G. Comparative evaluation of tree lucerne (Chamaecytisus palmensis) over conventional protein supplements in supporting growth of yearling horro lambs. Livest Res Rural Dev. 2012:24.

44. ARC. The nutrient requirements of ruminant livestock, technical review Agricultural Research Council working party. ARC (Agricultural Research Council), 1980.

45. Ranjihan S K Animal nutrition in the tropics. 4th eds. Vikas publishing House P. Ltd. New Delhi, India. 1997, p. 557.

46. AFRC. Energy and protein requirements of ruminants. AFRC (Agricultural Food and Research Council), An advisory manual prepared by Agricultural Food and Research Council technical committee on responses to nutrients. CAB int. Wallinaford, UK. 1993, p. 342

Ready to submit your research? Choose BMC and benefit from

- fast, convenient online submission

- thorough peer review by experienced researchers in your field

- rapid publication on acceptance

- support for research data, including large and complex data types

- gold Open Access which fosters wider collaboration and increased citations

- maximum visibility for your research: over 100M website views per year

At $\mathrm{BMC}$, research is always in progress.

Learn more biomedcentral.com/submissions 